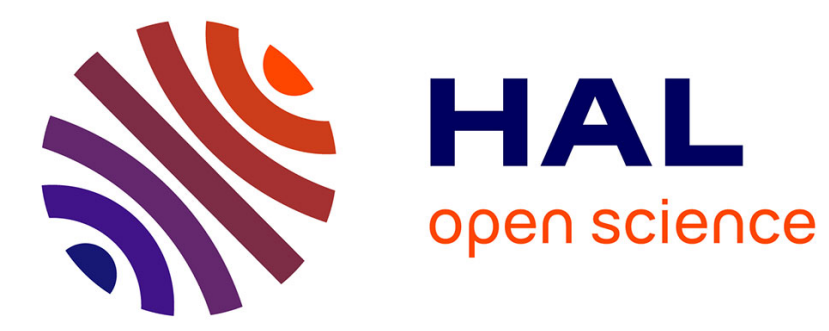

\title{
International courts and the jurisprudence of statehood
}

Samantha Besson

\section{To cite this version:}

Samantha Besson. International courts and the jurisprudence of statehood. Transnational Legal Theory, 2019, 10 (1), pp.30-64. 10.1080/20414005.2019.1599672 . hal-02516258

\section{HAL Id: hal-02516258 \\ https://hal.science/hal-02516258}

Submitted on 3 May 2020

HAL is a multi-disciplinary open access archive for the deposit and dissemination of scientific research documents, whether they are published or not. The documents may come from teaching and research institutions in France or abroad, or from public or private research centers.
L'archive ouverte pluridisciplinaire HAL, est destinée au dépôt et à la diffusion de documents scientifiques de niveau recherche, publiés ou non, émanant des établissements d'enseignement et de recherche français ou étrangers, des laboratoires publics ou privés. 
archives-ouvertes

\section{International courts and the jurisprudence of statehood}

Samantha Besson

\section{To cite this version:}

Samantha Besson. International courts and the jurisprudence of statehood. Transnational Legal Theory, 2019, 10 (1), pp.30-64. 10.1080/20414005.2019.1599672 . hal-02516258

\section{HAL Id: hal-02516258 \\ https://hal.archives-ouvertes.fr/hal-02516258}

Submitted on 3 May 2020

HAL is a multi-disciplinary open access archive for the deposit and dissemination of scientific research documents, whether they are published or not. The documents may come from teaching and research institutions in France or abroad, or from public or private research centers.
L'archive ouverte pluridisciplinaire HAL, est destinée au dépôt et à la diffusion de documents scientifiques de niveau recherche, publiés ou non, émanant des établissements d'enseignement et de recherche français ou étrangers, des laboratoires publics ou privés. 


\title{
International courts and the jurisprudence of statehood* $^{*}$
}

\section{Samantha Besson}

Professor, Public International Law and European Law, University of Fribourg, Fribourg, Switzerland

\begin{abstract}
International courts (ICs) have not only been specifying States' duties, but have also contributed to the definition of States themselves. The article focuses on the case-law of three ICs: the International Court of Justice qua generalist international law court, and its making of the 'internationalised State'; the European Court of Human Rights qua regional human rights court, and its moulding of the 'democratic State'; and the Court of Justice of the European Union qua court of a regional economic organisation, and its making of the 'managerial State'. The first part assesses the role of ICs in the development of the international law of statehood. The second part identifies the making of the State in the three ICs' case-law and compares the ways in which statehood is actually performed through international jurisprudence. A third part presents three critiques of the contemporary international jurisprudence of statehood and explores ways to reform it.
\end{abstract}

KEYWORDS International courts; statehood; ICJ; ECtHR; CJEU

\section{Introduction}

Over the years, international courts (ICs) have not only been specifying the existence, content and scope of States' specific duties and responsibilities under various regimes of international law, but, so-doing, they have also contributed to the continuous legal definition and delineation of States themselves.

That contribution of ICs' case-law to the international law of statehood is what one may refer to as the international 'jurisprudence of statehood'. The term 'jurisprudence' of statehood has been chosen for two reasons: first, to distinguish it from the more general regime of the international law of statehood, of which jurisprudence is just one part and a recent one, albeit an important one, as we will see; and, second, to emphasise, given the encom-

CONTACT Samantha Besson samantha.besson@unifr.ch

*This article originates from the PluriCourts Annual Lecture presented at the University of Oslo on 21 June 2018. 
passing meaning of the term 'jurisprudence' in English, the importance of the legal theoretical or philosophical work done by ICs with respect to the concept of statehood. ${ }^{1}$

At first sight, the topic may sound counterintuitive. After all, ICs are often considered as the epitome of global governance and of international lawmaking 'beyond the State'. ${ }^{2}$ One would not expect them therefore to be very interested in States except as one of the many 'agents' of enforcement of international law, or to have contributed much to their conceptualisation in international law. Most ICs, indeed, developed at a time at which international lawyers thought that international courts could deliver universal justice through a single and globalised international law. ${ }^{3}$ Many scholars even hoped ICs could help overcome the parochial divisions of international politics, and especially those arising from what was perceived by them as the common abuse of individual rights and interests by sovereign States.

As we now know, this post-war and especially post-1990s (and largely European or Western) project has been short-lived. In many ways, indeed, certain ICs may have successfully freed themselves from States or, at least, forced themselves onto them in the making of international law. So-doing, however, they have themselves become an instrument of international legal managerialism, often imposed at the price of international politics. ${ }^{4}$

Based on this assessment, it has been rightly suggested that international lawyers and scholars should take back the moral-political high ground of international law. ${ }^{5}$ What they need to do is go back to central institutional or political questions in international law. ${ }^{6}$ With this change of focus, most international lawyers concerned with the political or institutional dimension of international law have moved away from the study of ICs, leaving the latter to international relations theorists and moral philosophers. ${ }^{7}$ They would be well advised, however, not to disregard ICs too quickly. It is important, on the contrary, to start by assessing what has been the contribution of ICs to international institutional law and then to identify ways of reforming their practice in the future.

The best place to start this new line of international institutional enquiry is, I submit, to focus on ICs' contribution to the international law of statehood.

\footnotetext{
${ }^{1}$ See Ronald Dworkin, Law's Empire (Harvard University Press, 1991) 90: 'Jurisprudence is the general part of adjudication, silent prologue to any decision at law'.

2 See José Alvarez, The Impact of International Organizations on International Law (Brill, 2017) 262ff and esp $285 \mathrm{ff}$.

${ }^{3}$ See Rene Urueña, 'Law-Making through Comparative International Law?' in R Liivoja and J Petman (eds), International Law- Making: Essays in Honour of Jan Klabbers (Routledge, 2014) 149-61, $156 \mathrm{ff}$.

${ }^{4}$ See Martti Koskenniemi, 'Global Governance and Public International Law' (2004) 37 Kritische Justiz 241.

${ }^{5}$ See Martti Koskenniemi, 'The Fate of Public International Law: Between Technique and Politics' (2007) 70 Modern Law Review 1; Martti Koskenniemi, 'The Politics of International Law - 20 Years Later' (2009) 1 European Journal of International Law 7.

${ }^{6}$ See Samantha Besson and José Luis Martí, 'The Legitimate Actors of International Law-Making - Towards a Theory of International Democratic Representation' (2018) 9(3) Jurisprudence 503.

7 See eg, Nienke Grossman, Harlan Grant Cohen, Andreas Føllesdal and Geir Ulfstein (eds), Legitimacy and International Courts (Cambridge University Press, 2018).
} 
There are many reasons for this. First of all, States were the first international law institutions and remain the most important ones today. True, this has often been occulted by what one may refer to as everyday 'anthropomorphism' in international law $^{8}$ and the tendency to treat the State as one legal 'subject' or 'actor' among others rather than as an institution of international law-making. To that extent, States are an inescapable component of what some have misguidedly called politics or international law-making 'beyond the State'. They should therefore be the first institution we should theorise and mobilise in an effort to approach the political and institutional structure of international law, well before focusing on international organisations (IOs) or other (non-State) 'actors'. To do so, however, we need to know what the international legal status of contemporary States is and cannot rely on a largely mythological Westphalian international law of statehood.

Second, the contemporary international law of statehood is, although the story is less well-known, largely a product of ICs' jurisprudence. It is indeed thanks to the Permanent Court of International Justice's (PCIJ) and the International Court of Justice's (ICJ) early case-law that the main building blocks of the international law of statehood were placed. They were followed in this respect by other ICs in specific regimes of international law and in particular regions. Provided it is reformed, therefore, ICs' case-law has the potential to contribute to the institutional debate in international law.

Finally, approaching ICs as makers of the international law of statehood is, at first sight, conceptually and normatively intriguing for two reasons. First, one should mention the famous tension between law and politics regarding the creation, modification and dissolution of institutions such as States, and the contested relevance and, by extension, justification of (international) law in this respect: ${ }^{9}$ it makes the question of whether there could actually be judicial (international) law of statehood even more controversial. A second reason to be interested is the alleged amour impossible between States and ICs that have often been said to compete for the power to make international law. ${ }^{10}$ Once international adjudication is approached as part of international law-making albeit of a special kind, the question of who

\footnotetext{
${ }^{8}$ See Jean d'Aspremont, 'The Doctrine of Fundamental Rights of States and Anthropomorphic Thinking in International Law' (2015) 4(3) Cambridge Journal of International and Comparative Law 501.

${ }^{9}$ See Janis Grzybowski and Martti Koskenniemi, 'International Law and Statehood: A Performative View' in R Schuett and PMR Stirk (eds), The Concept of the State in International Relations: Philosophy, Sovereignty and Cosmopolitanism (Edinburgh University Press, 2015) 23-47; Jean d'Aspremont, 'The International Law of Statehood: Craftsmanship for the Elucidation and Regulation of Births and Deaths in the International Society' (2014) 29 Connecticut Journal of International Law 201; Jean d'Aspremont, International Law as a Belief System (Cambridge University Press, 2018) 83; Jean d'Aspremont, 'The International Law of Statehood and Recognition: A Post-Colonial Invention' in T Garcia (ed), La reconnaissance du statut d'Etat à des entités contestées (Pedone, 2018) 15-28.

${ }^{10}$ See Samantha Besson, 'Legal Philosophical Issues of International Adjudication - Getting Over the amour impossible between International Law and Adjudication' in KJ Alter, CPR Romano, and Y Shany (eds), The Oxford Handbook of International Adjudication (Oxford University Press, 2014) 413-34.
} 
between States and ICs should be making the international law of statehood becomes even more interesting.

Of course, a complete assessment of the international jurisprudence of statehood would require a survey of the case-law of all ICs to which States are subjected to. This goes well beyond the capacity of this article, however. Instead, it focuses on the case-law of three ICs that have contributed to three dimensions of the international law of statehood in contemporary Europe: the ICJ qua sole universal and generalist international law court, and its making of the 'internationalised State'; the European Court of Human Rights (ECtHR) qua regional human rights court, and its moulding of the 'democratic State'; and the Court of Justice of the European Union (CJEU) qua court of a regional economic international organisation, and its making of the 'managerial State'.

This article's argument is three-pronged. In the first part, it assesses the current state of the international law of statehood and discusses what has been the role of ICs in its development (2). The second part of the argument delves deeper into each of the three selected ICs' case-law in order to identify how the making of the (respectively 'internationalised', 'democratic' and 'managerial') State works therein and to compare the ways in which statehood is actually performed through international jurisprudence (3). A third section of the article criticises the state of the international jurisprudence of statehood and explores ways in which one could reform it (4).

In a nutshell, the proposal is, first, to make the international jurisprudence of statehood more comparative of the ways in which different States work, and hence to enhance its regional or universal justification and overcome the imperialism of the international law of statehood; second, to make it more normatively critical, and hence to overcome both its original dogmatic selfreferentiality and the quasi-scientific or even economic objectivity it has come to rely on over time; and, finally, to make the international jurisprudence of statehood more political, and hence to reveal the relationship of representation that underpins statehood in international law and links it to both governments and peoples and, thereby, to bring back political legitimacy concerns at the core of the international law of statehood but also, by extension, of international institutional law.

\section{The state of the international law of statehood}

\subsection{The origins of the international law of statehood}

The international law of statehood is the regime of international law that pertains to the institution that we call the State. As we will see below, its various norms regulate the constitution and dissolution of States, but also their various powers, rights, duties and responsibilities while they are in existence. 
Although they originally applied only to the external relations of States to one another, they now also pertain to States' internal organisation and to their relations to their population.

Surprisingly, the international law of statehood is a recent regime of international law. Of course, modern international law was from its very origins a law of and about States to the extent that States were, and arguably still are, the primary makers of international law and international law was mostly about their relations to one another. This relationship of mutual constitution between States and international law is sometimes referred as immédiateté in French to signal that one necessarily goes with the other. It is precisely, however, because States were, for a long time, the only law-makers and legal subjects of international law that it would have been tautological to even consider a legal regime pertaining to statehood within international law itself.

True, the same self-referentiality could be said to apply, within modern domestic law, between the State and its domestic legal order. And this has not prevented domestic law from developing public law norms pertaining to the organisation of the State, even if modern public law is a relatively recent occurrence. If domestic law could regulate the State whose public law it was, international law could a fortiori do the same for the many States whose public law it was and a law which States shared as a condition of their equal sovereignty. What explained the reluctance of classical international law to even grasp States as a legal concern was anthropomorphism. That approach characterised the liberal conceptualisation of statehood that dominated international law in the eighteenth, but also nineteenth Centuries. On that conception, States in the international legal order were understood as the natural persons of the domestic legal order. To that extent, their existence was, like that of human beings and unlike that of the State in domestic law, treated as an objective truth that could be established quasi-scientifically ('naturally', one would have said) and did not depend on legal recognition. ${ }^{11}$

It is only in the late nineteenth Century, but even more clearly in the early twentieth Century that international law started developing legal norms on statehood. This occurred for two reasons and in two steps. First, with the civilising mission of colonisation, but more clearly with what later became the developing promise of decolonisation in the 1950s and 1960s, European and then Western States, that had ventured outside of Europe and the West, progressively universalised their institutional model by expanding it to the rest of the world. That 'import' or 'export' enterprise and, depending on the cases, imposition or reception of statehood occurred in various ways in different parts of the world. ${ }^{12}$ For that purpose, however, and in order to

\footnotetext{
${ }^{11}$ See also d'Aspremont, 'The International Law of Statehood' (n 9).

${ }^{12}$ See Martin van Creveld, The Rise and Decline of the State (Cambridge University Press, 1999); Bertrand Badie, The Imported State: The Westernization of the Political Order (Stanford University Press, 2000).
} 
control and regulate the new States that were emerging, an international law of statehood was required and gradually developed. It helped specifying the criteria of statehood one could apply to identify new States in the image of the original European ones. ${ }^{13}$ Common criteria of statehood were actually already shared by most European philosophical traditions of statehood, however different those were in other respects. ${ }^{14}$ They had gradually gelled into a common practice of Western States and, once universalised, became a central piece of the new international law of statehood. In modern terms, they are a distinct territory, a permanent population, an internally and externally effective government, and independence.

Second, and a few years later, with the development of IOs, the need arose to specify what those new international institutions' rights, duties and responsibilities would be and hence what kind of legal personality international law should grant them. This required delineating IOs from States, and this became the second role of the international law of statehood. That delineation occurred by emphasising the original, plenary and general nature of States' rights and powers by opposition to the derivative, limited and relative rights and powers of IOs, thereby re-affirming States' priority as immediate subjects of international law.

Those two roles of the international law of statehood, ie, defining statehood and delineating it, are still at play today. Of course, the circumstances of statehood and other international institutions have changed, but the need to control statehood and to organise the State's relations to other institutions is even stronger nowadays than it was in the twentieth Century. Indeed, new States keep emerging, albeit in different contexts; IOs have become more autonomous and inter-relate; and other international institutional actors have arisen whose legal personality is still in question.

As a matter of fact, the two roles of the international law of statehood are often combined these days. This is because, first of all, IOs are now participating in the definition of statehood. ${ }^{15}$ This is done through their ICs provided they have courts, but not only. Those ICs have indeed contributed to turning their IO's Member States into instruments to serve the functions that those very States vested the IO with in the first place. Secondly, Member States have become deeply integrated to one another in their (supranational) IO. This has led the legal personality of all Member States and, arguably, that of their organisation itself to evolve together towards a new kind of integrated legal personality.

${ }^{13}$ See Judge Forster, Separate Opinion, ICJ, Western Sahara (Advisory Opinion) [1975] ICJ Rep 1975 12, p 103: '[Africa's] institutions should be a carbon copy of European institutions'.

${ }^{14}$ See Quentin Skinner, 'The Sovereign State: A Genealogy' in Q Skinner and H Kalmo (eds), Sovereignty in Fragments: The Past, Present, and Future of a Contested Concept (Cambridge University Press, 2010) 2646.

${ }^{15}$ See Guy Fiti Sinclair, To Reform the World. International Organizations and the Making of Modern States (Cambridge University Press, 2017). 
While the international law of statehood first pertained to the regulation of States' relations in the international legal order, it has gradually evolved, since the end of the Second World War and with the development of international human rights law, but especially since the end of the Cold War, to also address the internal organisation of the State itself, and in particular issues of institutional organisation and political regime. This echoed a corresponding change in the domestic public law of statehood that took place, depending on the States, mostly in the early or second half of the twentieth Century, ie, the re-discovery of popular sovereignty, and of the inherent democratic limits on State authority as legitimate authority, and the entrenchment of constitutional democracy. From that moment onwards, the distinction between the international and the domestic laws of statehood has become increasingly moot.

\subsection{The role of international courts in the international law of statehood}

ICs were the first international law-making forum in which the international law of statehood was consolidated as a regime of international law in the twentieth Century. Their contribution to the international jurisprudence of statehood started with decisions or opinions by arbitral tribunals, and the Permanent Court of Arbitration (PCA) in particular. ${ }^{16}$ Those were later followed by the case-law of the PCIJ ${ }^{17}$ and the ICJ, and more recently of other ICs.

Thanks to their dispute-settlement and advisory powers, ICs have contributed, in their interpretation of international law, to the identification of the practice of States with respect to statehood. So-doing, they have either validated that practice as customary international law or general principles, ${ }^{18}$ or justified existing customary international law or general principles by enhancing their legitimacy. Once those customary norms and principles were codified, as they were in the case of certain fields of the international law of statehood such as the law of succession or immunities, ICs have contributed to the further interpretation of those treaties or other forms of 'progressive development' codifications such as those of the International Law Commission (ILC). ${ }^{19}$

${ }^{16}$ See eg, PCA, Island of Palmas (or Miangas) (The Netherlands / The United States of America) (Merits) [1928] PCA Case no 1925-01, pp 7-10.

17 See Ole Spiermann, 'General Legal Characteristics of States: A View from the Past of the Permanent Court of International Justice' in C Chinkin and F Baetens (eds), Sovereignty, Statehood and State Responsibility: Essays in Honour of James Crawford (Cambridge University Press, 2015) 144-52.

${ }^{18}$ See Donald Regan, 'International Adjudication: A Response to Paulus - Courts, Custom, Treaties, Regimes, and the WTO' in S Besson and J Tasioulas (eds), The Philosophy of International Law (Oxford University Press, 2010) 225-41.

${ }^{19}$ See eg, Alain Pellet, 'Shaping the Future of International Law: The Role of the World Court in LawMaking' in MH Arsanjani et al. (eds), Looking to the Future. Essays on International Law in Honor of W. Michael Reisman (Martinus Nijhoff Publishers, 2010) 1065-84. 
Of course, since then, other international institutions than ICs, and especially other organs or agents of IOs, have also contributed to the development of the international law of statehood. It has been the case most clearly of the United Nations (UN) General Assembly and Security Council through their various resolutions, ${ }^{20}$ but also of other bodies like the World Bank. ${ }^{21}$ Here again, ICs have been called to refer to those bodies' resolutions and to interpret them, thereby participating in the consolidation of the general international law of statehood.

There are many reasons for the specific role played historically by ICs' jurisprudence in the making of the international law of statehood, especially compared to other international law-making processes such as treaties or binding IO resolutions. A first explanation may be that the international law of statehood developed and consolidated at a time, as I explained before, where besides international treaties among States, there were very few other universal international fora where such law could be made or, at least, customary international law could be identified, interpreted and justified. ${ }^{22}$ IOs were few and hardly any of their resolutions were binding. Treaties were difficult to conclude on issues where States were unequally situated or between States and 'non-self-governing entities' claiming to be States. A second, and related, reason had to do with the ways in which issues in the international law of statehood arose, ie, in concrete cases and mostly in contentious ones. The dispute resolution power or, at least, advisory power of the ICJ was uniquely situated therefore to contribute to the making of the international law of statehood. Finally, one should also mention the kind of legal reasoning ICs can resort to and its particular adequacy to the conceptualisation of statehood in international law. Issues of statehood are not only abstract and difficult normatively, but, to the extent that statehood is a constitutive feature of the international legal order, settling them also requires a clear theoretical conception of the structure and justification of that order.

True, it is not uncommon for ICs to be said to contribute to the so-called 'development' of general international $\operatorname{law}^{23}$ and to be criticised for it. Without surprise, therefore, similar critiques have been raised against the international jurisprudence of statehood. The first critique echoes a general one that pertains to the existence and the legitimacy of the law-making

${ }^{20}$ Se eg, on Kosovo: Jean d'Aspremont, 'Regulating Statehood: The Kosovo Status Settlement' (2007) 20 Leiden Journal of International Law 649.

${ }^{21}$ Se eg, World Bank, World Development Report 1997: The State in a Changing World (Oxford University Press, 1997), p iii, 17.

22 See Ingo Venzke, 'The International Court of Justice during the Battle for International Law (1955-1975) - Colonial Imprints and Possibilities for Change' in J von Bernstorff and P Dann (eds), The Battle for International Law in the Decolonization Era (2019) (forthcoming).

${ }^{23}$ See Bing Bing Jia, 'International Case Law in the Development of International Law', (2017) 382 Collected Courses of the Hague Academy of International Law 175; Christian J Tams, 'The ICJ as a "Law-Formative Agency": Summary and Synthesis' in CJ Tams and J Sloan (eds), The Development of International Law by the International Court of Justice (Oxford University Press, 2013) 377-96. 
powers of ICs. ${ }^{24}$ A second critique pertains to the theoretical, and some may even argue logical incoherence or lack of plausibility of having courts, that are themselves secondary institutions of international law-making, deciding over other secondary rules or principles of international law and even applying other secondary rules of international law to decide over them. ${ }^{25}$

This is not the place to expand at great length about either of those critiques. Let me say, however, with respect to the first issue, that it is made even more interesting by the fact that States and ICs are usually described as institutions competing for the right to make international law. ${ }^{26}$ If ICs are to be seen as vested with the power to mould States themselves through the making of the international law of statehood, then their law-making power clearly becomes even more controversial. Once the fictive personal nature of the State is clarified, however, and especially the role of law in sustaining that institutional fiction, there is nothing surprising in the role international law is called to play in the making of the international State, including through the international judiciary. Of course, we should not overestimate or single out the legal dimension of any institution, including statehood, but this does not mean we should underestimate it either. Furthermore, the fact that ICs are themselves legally constituted by States as competing international law-makers does not make the argument circular: it merely reflects the fact that even though States are still our main legal institutions both at the domestic and international level, they are no longer our sole institutional representatives internationally. The identity of the international institutions in charge of making the international law of statehood should therefore reflect that evolution.

As to the second critique, while it is correct to be concerned about the coherence of arguments in which secondary rules are routinely invoked by ICs to decide over other secondary rules, it does not seem to cut any ice with respect to the jurisprudence of statehood. To the extent, as I argued before, that States themselves can make international law about statehood and that ICs can also contribute as international institutions to that lawmaking process, it is difficult to see how this could occur outside the framework of international law-making itself and its respective sources. Of course, those law-making processes rely quite self-referentially for their working on the existence of States. However, this kind of self-referentiality is not perceived as problematic domestically where parliaments and courts are constituted by law and decide over constitutional matters of statehood, and there is no reason it should be considered more problematic

\footnotetext{
${ }^{24}$ See d'Aspremont, 'Statehood and Recognition' (n 9); d'Aspremont, 'The International Law of Statehood' (n 9).

${ }^{25}$ See Jean d'Aspremont 'The International Court of Justice and the Irony of System-Design' (2017) 8(2) Journal of International Dispute Settlement 366.

${ }^{26}$ See the discussion in Besson, 'Legal Philosophical Issues of International Adjudication' (n 10).
} 
internationally. Quite the contrary, actually, to the extent that there is more than one State in the international legal order.

A third, and more specific critique of ICs' jurisprudence of statehood has been the lack of customary international law on statehood, at least before ICs issued most of their judgments or opinions on that law. It pertains therefore to the largely 'mythological' references to such pre-existing sources in ICs' caselaw. ${ }^{27}$ That critique is usually launched with respect to the widespread references to the 1933 Montevideo Convention in this context. To the extent that it pertains to the invocation of the latter's role as a 'repository' of alleged customary criteria of statehood, to quote d'Aspremont, ${ }^{28}$ that critique needs to be taken seriously. It does not affect the validity or legitimacy of ICs' jurisprudence of statehood per se, however.

To start with, the reason the Montevideo Convention has been repeatedly invoked as source or, at least, as evidence of the four criteria of statehood mentioned before is not as mysterious as it sounds. It is indeed the only written provision we have to date pertaining to those criteria in international law. As a matter of fact, it not so surprising that the Montevideo Convention even included a provision on the criteria of statehood in the first place. Of course, the intent of the Latin American States parties was clearly not to spell out a universal conception of statehood, but to strike a clean break from the then European international law's civilising and hence subjective approach to statehood and its recognition. The criteria of statehood listed in the Montevideo Convention were, however, common to many theories of the modern State in different Western political and legal cultures and were actually practised in those States and domestic legal orders.

That being said, it is important to emphasise that the Montevideo Convention itself could not be considered as customary, even at the regional level. As the ICJ argued in the Asylum case, the Convention had not been very broadly ratified in Latin America where it applied, and, even there, it could not be said to have customary value. ${ }^{29}$ As a matter of fact, unlike countless international law textbooks and certain international law scholars, ${ }^{30}$ ICs have only rarely referred to the Montevideo Convention as evidence of the customary nature of the international law of statehood. ${ }^{31}$

\footnotetext{
${ }^{27}$ See d'Aspremont (n 25).

${ }^{28}$ See d'Aspremont, International Law as a Belief System (n 9) 79-86; Thomas D Grant, 'Defining Statehood: The Montevideo Convention and its Discontents' (1998-9) 37 Columbia Journal of Transnational and International Law 403.

29 See ICJ, Asylum (Colombia v Peru) (Merits) [1950] ICJ Rep 266, paras 274-8 and 277.

${ }^{30}$ See eg, David Bederman, The Spirit of International Law (University of Georgia Press, 2002), 49; Jure Vidmar, 'The Concept of the State and its Right of Existence' (2015) 4 Cambridge Journal of International and Comparative Law 547.

${ }^{31}$ For an exception, albeit an arbitral and ancient one, see Germano-Polish Mixed Arbitral Tribunal, Deutsche Continental Gas-Gesellschaft v Polish State (1929) 5 Annual Digest of Public International Law Cases 11.
} 
Of course, this third critique rightly points to the dogmatic and, one may argue, quasi-theological way in which the international jurisprudence of statehood has developed in general, even outside of references to the Montevideo Convention. Importantly, however, what one may refer to as the performative legality or 'self-fulfilling legalism' of statehood should not necessarily come as a surprise. Again, the same may be said of the domestic (constitutional) law of statehood to the extent that modern domestic law is the law of a State, and vice-versa.

\section{International courts' jurisprudence of statehood}

\subsection{A map of the international jurisprudence of statehood}

This section proposes a comparative presentation of the jurisprudence of statehood by three selected ICs: the ICJ, the ECtHR and the CJEU. This makes for an interesting comparison between the case-law of a universal and generalist IC (the ICJ), and that of two regional and specialised ICs in Europe: one in the field of European human rights law (the ECtHR) and the other in that of European Union (EU) law (the CJEU).

Broaching the ICJ's jurisprudence of statehood first is a necessity given its central contribution to the development of the international law of statehood. As the only generalist IC in existence, the international law of statehood clearly belonged from the very beginning to the PCIJ's and the ICJ's core material jurisdiction. Those two courts' universal jurisdiction also provided them with the ability to internationalise statehood and a certain regime thereof. Focusing then on two regional ICs is a testimony to the importance of regional courts among ICs today and to their role in the development of general international law. Of course, the regional, but also the material focus of those two ICs affects the kind of theories of statehood underpinning their respective jurisprudence. Given the importance of trade and human rights among the regimes of specialised ICs, however, one may consider those two ICs as being representative of specialised international jurisprudence in Europe.

There are three ways in which the international jurisprudence of statehood has grown from the identification and interpretation of international law by ICs. ICs may, first of all, be interpreting the international law of statehood stricto sensu, as it is the case when they are applying general rules or principles of international law on State recognition or succession, be they customary or treaty-based. To the extent that the international law of statehood is part of general international law, it is applicable by all ICs. Secondly, ICs may also develop the international law of statehood through their interpretations of other general rules of international law such as international responsibility law or international law on sources. To the extent that those other areas of 
general international law apply to all States and in all regimes of international law, they belong to the law applied and interpreted by all three ICs. ICs may also, finally, be deriving rules and principles pertaining to statehood from the interpretation of another regime of international law, and especially from their own special regime in the case of specialised ICs.

ICs' jurisprudence of statehood may be organised under two main axes or dimensions of statehood in international law that correspond to the two aims and genealogical layers of the international law of statehood identified before: first, defining and, second, delineating statehood.

The first axis in the international jurisprudence of statehood pertains to defining statehood stricto sensu. It covers four sets of issues:

i The first set pertains to the constitutive features or criteria of statehood, and in particular a distinct territory, a permanent population, internal and external effective government, and independence.

ii The second set of issues relates to the beginning and the end of statehood. They cover questions related to self-determination, secession, recognition, on the one hand, and to succession or continuity, on the other.

iii The third group of questions has to do with the jurisdiction or powers of states, their rights, duties and responsibilities. States' powers are usually characterised as being comprehensive, exclusive and supreme and are grounded primarily on territory (territorial jurisdiction), but also extend beyond the official territory on grounds of nationality (personal jurisdiction), domestic interest (protective jurisdiction) or collective interest (universal jurisdiction). Among the rights of States, one should mention diplomatic protection and immunities in particular.

iv The fourth set of issues is also the most recent one in the international jurisprudence of statehood and pertains to the internal organisation of the State. That jurisprudence focuses on the rules and principles that ensure the self-limitation of States and ground their legitimate authority. One may distinguish between those rules and principles that pertain to the political regime and those that relate to other aspects of political organisation. The former entail principles such as, for instance, democracy, rule of law, separation of powers, judicial review, parliamentarism or proportional representation. International norms pertaining to political organisation include, among others, federalism, devolution, decentralisation, civil society or political parties.

The second axis in the international jurisprudence of statehood pertains to the delineation of States and the relations between States and other international law institutions and/or subjects: 
i The first relation to be regulated under the international jurisprudence of statehood has been the relation between States and IOs.

ii The second relationship is that between States and private actors. The latter include non-governmental organisations (NGOs), transnational corporations or armed groups, but the list is non-exhaustive and is defined negatively by reference to States themselves. Among the issues addressed by this sub-set of rules and principles of the international jurisprudence of statehood, one finds issues pertaining to those actors' legal personality, but also to the delineation of their respective responsibility regimes and States' duties of due diligence with respect to them.

To the extent that the international jurisprudence of statehood has developed with ICs themselves, its history matches that of ICs. This also goes for the specialisation and fragmentation of the international jurisprudence of statehood, therefore, depending on the IC and its regime. This has consequences for the international law of statehood that nowadays knows of different interpretations depending on the regions and the regimes considered. Of course, as often in cases of conflicting jurisprudential interpretations of general rules of international law, the IC whose jurisprudence is most authoritative is the ICJ's. As we will see, regional and specialised ICs, like the ECtHR or the CJEU, usually refer and sometimes even defer to the ICJ on matters related to the international law of statehood. Their special jurisdiction does not prevent them from providing different interpretations in certain cases, however, and, even more importantly, from developing, in the absence of ICJ case-law, a conception of statehood specific to their legal regime.

Of course, some of those differences may also be explained by reference to causes or reasons lying outside of their specific international law regime. A first ground for variations between the three ICs' jurisprudence may lie in the jurisdiction of each court, and in particular differences between their personal, temporal or territorial scope. The latter affects the kind of questions raised before an IC and the type of individual, State or IO interests defended before it, depending on whether individuals have legal standing or not and, even when they do, on how the IC's jurisprudence varies between such cases and those decided upon an interstate application. A second explanation may be the type of control and review each IC exercises, and in particular whether it is contentious or advisory. In turn, variations in the authority of an IC's decisions influence their content in the first place. A third ground relates to the compulsory nature of the jurisdiction of some ICs, while that of most others remains optional.

A fourth reason may reside in the period in which each IC's case-law was established and how it reacted to the state of the international law at that time. This is particularly important to understand the differences between various stages in the PCIJ's and ICJ's jurisprudence of statehood that spans over very 
distinct eras of international law, ranging from the height of Western imperialism, through post-colonialism, ${ }^{32}$ to this day. It also matters to understand differences between the PCIJ/ICJ's jurisprudence and that of the other two ICs that are post-war courts and whose jurisprudence bears the mark of the end of the Cold War in particular. A fifth, and related, ground pertains to the localisation of the IC and its territorial and hence scope of authority in relation to statehood. This influences the kind of either universal or regional (in this case, European) justifications that have to be provided for any given interpretation of statehood.

A final explanation for differences in the respective jurisprudences of statehood may lie in the institutional framework of the IC itself, and especially whether it is merely established by a treaty and the latter's States parties or whether it is the judicial organ of an IO. This does not only matter for the IC's jurisprudence pertaining to the relations between Member States and the given IO, but also to statehood itself to the extent that it often reflects the IO's (other organs') conception of statehood. That relation to an IO also matters for the extent to which the IC is vested with judicial lawmaking powers and their subsidiary nature or not. For instance, the CJEU is famous for its constitutional law-making powers over the EU and its Member States, and those powers can be contrasted with the ECtHR's subsidiary control within the European Convention on Human Rights (ECHR) system.

\subsection{Three international courts and their respective conception of statehood}

\subsubsection{The ICJ and the internationalised State}

The ICJ's jurisprudence of statehood has its roots in the early twentieth Century PCIJ's judgments and opinions, ${ }^{33}$ and has built on them from 1945 onwards. It spans therefore over more than a century, and this long tradition shows in both its scope and content.

What characterises the ICJ's jurisprudence of statehood has been the internationalisation' of the Western, and especially European at first, notion of statehood to the rest of the world thanks to its authority as the sole generalist and universal court of international law. What this means, more specifically, is that the Western legal criteria of statehood have been identified, specified and then universalised through that case-law, and not only interpreted

32 See Shabtai Rosenne, 'Decolonisation in the International Court of Justice' (1996) 8 African Journal of International and Comparative Law 564.

${ }^{33}$ Such as the cases, PCIJ, Nationality Decrees Issued in Tunis and Morocco on Nov. 8th, 1921 (Advisory Opinion) [1923] PCIJ Rep Series B No 4; PCIJ, S.S. Wimbledon (UK v Japan) (Merits) [1923] PCIJ Rep Series A No 1; PCIJ, Status of Eastern Carelia (Advisory Opinion) [1923] PCIJ Rep Series B No 5; PCIJ, S.S. Lotus (France v Turkey) (Merits) [1927] PCIJ Rep Series A No 10; PCIJ, Legal Status of Eastern Greenland (Denmark v Norway) (Merits) [1933] PCIJ Rep Series A/B No 53. 
through international jurisprudence once they had been universalised. NonWestern States and so-called 'non-self-governing entities' that did not know of statehood in the modern sense-or, at least, not in the way it was conceived by international law-were subjected to those criteria as if they did. Nowadays, one may consider that the criteria of statehood are formally internationalised and that, as I explained before, they have become an integral part of international customary law partly thanks to the international jurisprudence of statehood. The process of internationalisation of statehood carries on, however, with respect to new aspects of the international law of statehood, as we will see, and through the international jurisprudence pertaining to them.

Of course, the ICJ has also been a reluctant 'internationaliser' of statehood at times. It has famously left certain issues undecided, as with respect to the exact regime of succession to treaties. ${ }^{34}$ It has also carefully kept some questions at bay by delineating its jurisdiction in certain ways, as exemplified by its decision not to determine the existence of a right to secession and to become a State. ${ }^{35}$ True, in many of those cases, the ICJ's self-restraint matched the indeterminacy of the international law of statehood. The international law of recognition is a case in point in this respect. ${ }^{36}$

Without surprise in view of its universalising effects, the ICJ's jurisprudence of statehood has been characterised by the many individual opinions of judges and the plurality of divergent theoretical and cultural conceptions of statehood they have expressed. It is the case, for instance, of the separate opinions by Judges Ammoun, Boni and Forster in Western Sahara, ${ }^{37}$ by Judge Ajibola in Territorial Dispute Libya $v \mathrm{Chad}^{38}$ or by Judge Weeramantry in Bosnian Genocide. ${ }^{39}$ It is interesting to note that most of them pertain to those very issues in the international law of statehood over which international law was indeterminate before the ICJ's decision. One may have indeed considered before the ICJ's opinion in Western Sahara that the personal jurisdiction of a political institution over its people could matter as much as its territorial jurisdiction when deciding over the existence of a State, and maybe even more so. ${ }^{40}$ And one could have hoped before the

\footnotetext{
${ }^{34} \mathrm{ICJ}$, Application of the Convention on the Prevention and Punishment of the Crime of Genocide (Bosnia and Herzegovina $v$ Serbia and Montenegro) (Merits) [2007] ICJ Rep 43, paras 67ff.

$35 \mathrm{ICJ}$, Accordance with International Law of the Unilateral Declaration of Independence in Respect of Kosovo (Advisory Opinion) [2010] ICJ Rep 403, paras 49-56 and 82-3.

${ }^{36}$ See Tom Grant, 'How to Recognize a State (and not): Some Practical Considerations' in C Chinkin and F Baetens (eds), Sovereignty, Statehood and State Responsibility: Essays in Honour of James Crawford (Cambridge University Press, 2015) 192-208.

37 Judges Ammoun, Forster, and Boni, Separate Opinions, ICJ, Western Sahara (n 13) 83, 103, and 173.

38 Judge Ajibola, Separate Opinion, ICJ, Territorial Dispute (Libyan Arab Jamahiriya v Chad) (Merits) [1994] ICJ Rep 6, pp 51-92.

39 Judge Weeramantry, Separate Opinion, ICJ, Application of the Convention on the Prevention and Punishment of the Crime of Genocide (Bosnia and Herzegovina $v$ Serbia and Montenegro) (Preliminary Objections) [1996] ICJ Rep 595, pp 640ff.

${ }^{40} \mathrm{ICJ}$, Western Sahara (n 13).
} 
Bosnian Genocide judgment that State succession to certain humanitarian treaties could be deemed automatic. ${ }^{41}$

Based on the analytical map of the international jurisprudence of statehood presented in the previous section, the ICJ has contributed to both dimensions of the international law of statehood. The second is, of course, less developed but it also corresponds to a more recent dimension of the international law of statehood generally and there are inherent limitations to the ICJ's personal and material jurisdiction that prevent it from addressing those issues directly.

With respect to statehood tout court, first of all, the ICJ's jurisprudence has focused for the longest period on the identification and interpretation of the criteria of statehood. The emphasis was placed, at first, on nationality, thanks to diplomatic protection cases in particular. ${ }^{42}$ Territoriality also quickly became a central piece of the ICJ's statehood jurisprudence, and in particular regarding issues of title, ${ }^{43}$ border delimitation ${ }^{44}$ or regime. ${ }^{45}$ One should especially mention cases pertaining to: the creation of States, and in particular self-determination and secession; ${ }^{46}$ their extinction, and in particular succession as opposed to continuity; ${ }^{47}$ and their recognition. ${ }^{48}$ A third group of concerns in the ICJ's jurisprudence of statehood has been the jurisdiction of

${ }^{41}$ ICJ, Bosnian Genocide (n 34).

42 ICJ, Nottebohm Case (Liechtenstein v Guatemala) (Second Phase) [1955] ICJ Rep 4, pp 22-3; ICJ, Barcelona Traction, Light and Power Company, Limited (Belgium v Spain) (New Application: 1962) (Second Phase) [1970] ICJ Rep 3, paras 28-58; ICJ, Ahmadou Sadio Diallo (Republic of Guinea v Democratic Republic of the Congo) (Merits) [2010] ICJ Rep 639, para 65.

${ }^{43}$ ICJ, Corfu Channel case (Merits) [1949] ICJ Rep 4, pp 18 and 35; ICJ, Sovereignty over Pedra Branca/Pulau Batu Puteh, Middle Rocks and South Ledge (Malaysia v Singapore) (Merits) [2008] ICJ Rep 12, paras 273-7, 289-90, and 295-9; ICJ, Territorial and Maritime Dispute between Nicaragua and Honduras in the Caribbean Sea (Nicaragua $v$ Honduras) (Merits) [2007] ICJ Rep 659, paras 159, 162, and 172-208.

${ }^{44}$ ICJ, Aegean Sea Continental Shelf (Greece v Turkey) (Merits) [1978] ICJ Rep 3, paras 58-9; ICJ, North Sea Continental Shelf Cases (Federal Republic of Germany v Denmark; Federal Republic of Germany v Netherlands) (Merits) [1969] ICJ Rep 1969 3, para 46; ICJ, Continental Shelf (Tunisia v Libyan Arab Jamahiriya) (Merits) [1982] ICJ Rep 18, paras 99-101; ICJ, Territorial Dispute (Libyan v Chad) (n 38) paras 23-34, 42-5, and 57; ICJ, Frontier Dispute (Burkina Faso v Republic of Mali) (Merits) [1986] ICJ Rep 554, paras 20-6; ICJ, Land, Island and Maritime Frontier Dispute (El Salvador v Honduras: Nicaragua intervening) (Merits) [1990] ICJ Rep 92, paras 82-4; ICJ, Maritime Delimitation and Territorial Questions between Qatar and Bahrain (Qatar v Bahrain) (Merits) [2001] ICJ Rep 2001 40, paras 36-69, 165, 205-9, and 240; ICJ, Land and Maritime Boundary between Cameroon and Nigeria (Cameroon v Nigeria: Equatorial Guinea intervening) (Merits) [2002] ICJ Rep 303, paras 31-9, 65, and 207-9; ICJ, Maritime Delimitation in the Caribbean Sea And The Pacific Ocean (Costa Rica v Nicaragua) and Land Boundary in the Northern Part of Isla Portillos (Costa Rica v Nicaragua) (Merits) [2018] not published yet, paras 59ff.

${ }^{45}$ ICJ, International Status of South West Africa (Advisory Opinion) [1950] ICJ Rep 128, pp 131-42 and 1505; ICJ, Legal Consequences for States of the Continued Presence of South Africa in Namibia (Namibia) notwithstanding Security Council Resolution 276 (1970) (Advisory Opinion) [1971] ICJ Rep 16, paras 52, 100, 118-119, and 131; ICJ, Western Sahara (n 13) paras 87ff.

${ }^{46}$ ICJ, South West Africa (n 45); ICJ, Western Sahara (n 13) paras 54ff; ICJ, East Timor (Portugal v Australia) (Merits) [1995] ICJ Rep 1995 90, paras 29ff; ICJ, Legal Consequences of the Construction of a Wall in the Occupied Palestinian Territory (Advisory Opinion) [2004] ICJ Rep 136, para 88; ICJ, Kosovo (n 35) paras 79ff; ICJ, Legal Consequences from the Chagos Archipelago from Mauritius in 1965 (Advisory Opinion) [2019] ICJ Rep 1.

47 ICJ, Bosnian Genocide (n 39); ICJ, Gabčíkovo-Nagymaros Project (Hungary v Slovakia) (Merits) [1997] ICJ Rep 19977.

48 ICJ, Namibia (n 45) paras 123-7; ICJ, Kosovo (n 35) paras 51-2; ICJ, Frontier Dispute (n 44) paras 20-6; ICJ, Nuclear Tests (Australia v France) (Merits) [1974] ICJ Rep 253, paras 47ff. 
States, and in particular the scope and content of their territorial and personal jurisdiction, ${ }^{49}$ but also of universal jurisdiction. ${ }^{50}$

An area in which the ICJ's jurisprudence of statehood has remained limited is the internal organisation of States, and in particular the latter's regime and political organisation. For instance, the Court chose to hide behind the inter-temporal rule in international law not to recognise members of the mandate system in South West Africa, subjected to South African apartheid, any right to require the due performance of the Mandate in discharge of the 'sacred trust ${ }^{51}$ It also famously refused to consider that international customary law committed a State to hold free elections. ${ }^{52}$ To this date, the ICJ has remained agnostic about such issues leaving them to other more specialised ICs or even non-judicial bodies whose authority it considers established under international law. ${ }^{53}$

A second tier of judgments and opinions by the ICJ pertains to the relations of States to IOs and private actors. With respect to IOs, first of all, the ICJ has famously clarified the characteristics of the legal personality of States when compared to that of IOs. ${ }^{54}$ It has also contributed, at the same time, to specifying what in the international law of statehood, and especially the powers, rights, duties and responsibilities of States, could be transposed mutatis mutandis to IOs. ${ }^{55}$ Further, the ICJ has contributed to the universalisation and entrenchment of the private/public distinction in international statehood law, and hence to the specification of the relations between States and private actors. This has happened mostly through its jurisprudence on the attribution of conduct of private agents to States in international responsibility law, ie, a large part of the one third of ICJ cases that pertains to State responsibility. ${ }^{56}$ This has also taken place through the ICJ's case-law on the immunities of the members of the 'triad' considered as specific State organs. ${ }^{57}$

49 ICJ, Asylum (n 29) pp 274-8.

${ }^{50}$ ICJ, Questions relating to the Obligation to Prosecute or Extradite (Belgium v Senegal) (Merits) [2012] ICJ Rep 422, paras 74ff; ICJ, Arrest Warrant of 11 April 2000 (Democratic Republic of the Congo v Belgium) (Merits) [2002] ICJ Rep 3, paras 41ff.

51 ICJ, South West Africa (Liberia v South Africa) (Merits) [1962] ICJ Rep 319.

52 ICJ, Military and Paramilitary Activities in and against Nicaragua (Nicaragua v United States of America) (Merits) [1986] ICJ Rep 14, paras 258ff.

53 ICJ, Diallo (n 42) para 65.

${ }^{54}$ ICJ, Reparation for Injuries Suffered in the Service of the United Nations (Merits) [1949] ICJ Rep 174, pp 178-80; ICJ, Certain Expenses of the United Nations (Article 17, paragraph 2, of the Charter) (Advisory Opinion) [1962] ICJ Rep 151, pp 167-8; ICJ, Difference Relating to Immunity from Legal Process of a Special Rapporteur of the Commission on Human Rights (Advisory Opinion) [1999] ICJ Rep 62, paras 62ff.

${ }^{55}$ ICJ, UN Reparation (n 54) pp 178ff; ICJ, Certain Expenses (n 54) pp 167ff; ICJ, Interpretation of the Agreement of 25 March 1951 between the WHO and Egypt (Advisory Opinion) [1980] ICJ Rep 73, paras 46ff; ICJ, Special Rapporteur (n 54) paras 62ff.

${ }^{56}$ ICJ, Nicaragua v United States of America (n 52), 113ff; ICJ, United States Diplomatic and Consular Staff in Teheran (United States of America v Iran) (Merits) [1980] ICJ Rep 3, paras 69-75 and 92; ICJ, LaGrand (Germany v United States of America) (Merits) [2001] ICJ Rep 446, para 28; ICJ, Armed Activities on the Territory of the Congo (Democratic Republic of the Congo $v$ Uganda) (Merits) [2005] ICJ Rep 168, paras 172-80; ICJ, Bosnian Genocide (n 39) paras 385ff.

57 ICJ, Arrest Warrant (n 50) paras 52ff; ICJ, Jurisdictional Immunities of the State (Germany v Italy, Greece intervening) (Merits) [2012] ICJ Rep 99, paras 52ff. 


\subsubsection{The ECtHR and the democratic State}

The international law of statehood does not belong to the core of the ECtHR's mandate to the extent that the ECHR does not materially regulate statehood. All the same, the Court's interpretation of the international law of statehood has developed gradually and alongside its human rights jurisprudence. The ECtHR's jurisprudence of statehood spans therefore over more than twenty years, and even more if one refers to the time prior to the compulsory jurisdiction of the Court within the ECHR system.

What characterises the ECtHR's jurisprudence of statehood has been its conceptualisation of what one may refer to as the 'democratic' State. The Court has indeed interpreted the States Parties' human rights duties under the ECHR as requiring the establishment of a democratic regime. ${ }^{58}$

Of course, democracy is protected by the ECHR in at least three different ways: as an aim in the Preamble; as specific democratic rights protected by the Convention and its Protocols (article 10 and 11 ECHR); and as the 'necessity in a democratic society' condition weighing on the justification of domestic restrictions of ECHR rights (eg, article 9(2) ECHR). As I will argue, the Court's case-law has gone one step further, however, and specified a general positive duty for each State Party to be organised democratically. Along the road, and as we will see below, this has been interpreted further as encompassing various principles such as the separation of powers, ${ }^{59}$ judicial independence, judicial review, political parties, free elections and political pluralism. The ECtHR has also drawn other implications from this democratic requirement of the ECHR for its States Parties' political organisation. Those further requirements include in particular setting various limits on consociationalism, federalism or other forms of decentralisation to protect the individual equality of rights among ECHR right-holders in a given political community, ${ }^{60}$ including when those forms of organisation are propounded by minority-based political parties. ${ }^{61}$

${ }^{58}$ ECtHR, Ždanoka v Latvia App no 58278/00 (16 March 2006), paras 98ff; ECtHR, Refah Partisi (the Welfare Party) and Others $v$ Turkey App nos 41340/98, 41342/98, 41343/98 and 41344/98 (13 February 2003), paras 86-9; ECtHR, United Communist Party of Turkey and Others v Turkey App no 19392/92 (30 January 1998), paras 24ff; ECtHR, Christian Democratic People's Party v Moldova App no 28793/02 (14 May 2006), paras 62-70; ECtHR, Tănase v Moldova App no 7/08 (27 April 2010), paras 154 ff; ECtHR, Party for a Democratic Society (DTP) and Others v. Turkey App nos 3840/10, 3878/10, 15616/10, 21919/10, 39118/10 and 37272/10 (6 June 2016), paras 72-82; ECtHR, Şahin Alpay v Turkey App no 16538/17 (20 March 2018), para 180; ECtHR, Navalnyy v Russia App 29580/12 (15 November 2018), para 175.

59 ECtHR, Animal Defenders International V UK App no 48876/08 (22 April 2013).

${ }^{60}$ ECtHR Case'relating to certain aspects of the laws on the use of languages in education in Belgium' $v$ Belgium App nos 1474/62, 1677/62, 1691/62, 1769/63, 1994/63, 2126/64 (23 July 1968), para 10; ECtHR, Mathieu-Mohin and Clerfayt App no 9267/81 (2 March 1987), paras 46ff; ECtHR, Sejdić and Finci v Bosnia and Herzegovina, App nos 27996/06 and 34836/06 (22 December 2009), paras 42ff.

${ }^{61}$ ECtHR, Herri Batasuna and Batasuna v Spain, App nos 25803/04 and 25817/04 (30 June 2009), paras 74ff; ECtHR, Partidul Comunistilor (Nepeceristi) and Ungureanu v Romania App no 46626/99 (3 February 2005), paras 46ff; ECtHR, Yazar and Others v Turkey, App nos 22723/93, 22724/93 and 22725/93 (9 April 2002), paras 40ff; ECtHR, Refah Partisi (n 58) paras 86-9; ECtHR, Öcalan v Turkey App no 46221/99 (12 May 
Interestingly, in the wake of its jurisprudence on the democratic regime and the internal organisation of States, the ECtHR has contributed to developing the international jurisprudence of statehood in general. With respect to statehood itself, on the one hand, the ECtHR's jurisprudence has recognised the existence of a general positive institutional duty to be an effective (democratic) State. Being an effective State is indeed regarded by the Court as an institutional condition for that State to then be able to respect, protect and fulfil its human rights duties under the ECHR. ${ }^{62}$ According to the Court, therefore, any State Party that has lost effective jurisdiction (in the sense of Article 1 ECHR) over its population and, by extension, over its official territory has a positive duty to regain that control. ${ }^{63}$ It is through that general institutional duty of States Parties to be effective democratic States that the Court has, in turn, come to mould various constitutive features of statehood in a new and distinctive way.

The ECtHR has, first of all, interpreted some of the international criteria of statehood related to territoriality, including regarding border jurisdiction, ${ }^{64}$ maritime jurisdiction ${ }^{65}$ or extraterritorial spatial control as in the case of occupation. ${ }^{66}$ It has also developed a jurisprudence on nationality, including on statelessness and arbitrary denial or voluntary renunciation to nationality. ${ }^{67}$ Secondly, the Court has contributed to the interpretation of the beginning and the end of statehood, by specifying States' duties in the context of succession $^{68}$ and recognition. ${ }^{69}$ Regrettably, however, it has mostly remained elusive on matters of self-determination and the right to secession under the

2005), paras 91-9; ECtHR, Süheyla Aydin v Turkey App no 25660/94 (24 May 2005), paras 164ff and 2003. See Helen Keller and Corina Heri, 'Minority and Secessionist Cases in the Case-Law of the European Court of Human Rights' in EM Belser et al. (eds), States Falling Apart? Secessionist and Autonomy Movements in Europe (Stämpfli, 2015) 103-24, 108-11.

${ }^{62}$ See ECtHR, Al-Skeini and Others v The United Kingdom App no 55721/07 (7 July 2011), paras 133ff.

${ }^{63}$ ECtHR, Loizidou v Turkey App no 15318/89 (18 December 1996), paras 49ff; ECtHR, Cyprus v Turkey App no 25781/94 (10 May 2001), paras 69ff; ECtHR, Banković and other v Belgium and others App no 52207/ 99 (12 December 2001), paras 55ff; ECtHR, Ilaşcu and Others v Moldova and Russia App no 48787/99 (8 July 2004), paras 310ff and 333ff; ECtHR, Solomou and Others v Turkey App no 36832/97 (24 June 2008), paras 43ff; ECtHR, Azemi v Serbia App no 11209/09 (18 February 2009), paras 38-49; ECtHR, Issa v Turkey App no 31821/96 (16 November 2011), paras 65ff; ECtHR, Al-Skeini (n 63) paras 133ff; ECtHR, Catan and Others v Moldova and Russia, App nos 43370/04, 8252/05 and 18454/06 (19 October 2012), paras 145ff; ECtHR, Jaloud $v$ the Netherlands App no 47708/08 (20 November 2014), paras 139ff; ECtHR, Sargsyan v Azerbaijan App no 40167/06 (16 June 2015), paras 126ff; ECtHR, Chiragov and Others v Armenia App no 13216/05 (16 June 2015), paras 167ff; ECtHR, Mozer v The Republic of Moldova and Russia App no 11138/ 10 (23 February 2016), paras 96ff; ECtHR, Tsezar and Others v Ukraine App no 73590/14, 73593/14, 73820/14, 4635/15, 5200/15, 5206/15, 7289/15 (13 February 2018), paras 73ff.

${ }^{64}$ ECtHR, N.D. and N.T. v Spain, App nos 8675/15 and 8697/15 (3 October 2017), paras 49ff.

${ }^{65}$ ECtHR, Hirsi Jamaa and Others v ltaly App no 27765/09 (23 February 2012), paras 70ff; ECtHR, Medvedyev and Others v France App no 3394/03 (29 March 2010), paras 62ff.

${ }^{66}$ ECtHR, Loizidou (n 63) paras 49ff; ECtHR, Ilaşcu (n 63) paras 310ff and 333ff; ECtHR, Sargsyan v Azerbaijan (n 63) paras 126ff; ECtHR, Chiragov (n 63) paras 167ff; ECtHR, Mozer (n 63) paras $96 \mathrm{ff}$.

67 ECtHR, Riener v Bulgaria App no 46343/99 (23 May 2006), paras 144ff; ECtHR, Kurić and Others v Slovenia App no 26828/06 (26 June 2012), paras 314ff; ECtHR, Hoti v Croatia App no 63311/14 (26 April 2018), paras $119 \mathrm{ff}$.

68 ECtHR, Bijelić v Montenegro and Serbia App no 11890/05 (28 April 2009), paras 67ff; ECtHR, Ribać v Slovenia App no 57101/10 (5 December 2017), paras 61ff; ECtHR, Andrejeva v Latvia App no 55707/00 (18 
ECHR by refusing to link one to the other. ${ }^{70}$ All the same, one may consider that the ECtHR has indirectly confirmed, when discussing State jurisdiction and the related positive duties, that a State (in that case, Serbia) may lose its duties to regain effective control over a population and territory that used to be its, when that population (in that case, Kosovo) has exercised self-determination. $^{71}$

Finally, the ECtHR has interpreted the content of some of the powers and rights inherent in statehood, and in particular the scope of the authorised or de jure extraterritorial jurisdiction of States ${ }^{72}$ or of their duties under the principle of universal jurisdiction. ${ }^{73}$ The Court has also, famously, contributed to identifying States' human rights duties on grounds of the effectiveness of the exercise of powers that are 'government'-like over another State's territory (what it refers to as 'jurisdiction' or 'control') even when that exercise of governmental powers is illegal. It is the case in particular of States' duties in circumstances of occupation. ${ }^{74}$ Generally, the ECtHR seems to be aware of the slippery-slope danger posed by its recognition of such occurrences of extraterritorial 'territorial' control. What it privileges as a ground for States' extraterritorial human rights duties therefore, where it can, is personal jurisdiction or control. ${ }^{75}$ Indeed, this kind of quasi-statehood duties owed in the territory and to the population of another State, even if the Court has recognised them in order to generate States' duties and not to grant them any rights, is controversial: it comes very close to giving priority, in the name of human rights protection, to quasi-governmental effectivity over democratic legitimacy and hence to condoning forms of illegal long-term occupation provided they respect human rights. ${ }^{76}$

On the other hand, the ECtHR's jurisprudence of statehood has also contributed to the second axis of the international law of statehood. First of all, the Court has developed an extensive case-law on the human rights duties of Member States of IOs with respect to the latter's actions or omissions, thereby moulding those States' relations to IOs. It is the case with respect

February 2009), paras 74ff; ECtHR, Government of the Republic of Slovenia v Republic of Croatia App no $54155 / 16$ (pending).

${ }^{69}$ ECtHR, Loizidou (n 63) paras 39ff; ECtHR, Cyprus v Turkey (n 63) paras 82ff; ECtHR, Demopoulos and Others v Turkey App nos 46113/99, 3843/02, 13751/02, 13466/03, 10200/04, 14163/04, 19993/04, and 21819/04 (1 March 2010), paras $72 \mathrm{ff}$.

${ }^{70}$ ECtHR, Gorzelik and Others v Poland App no 44158/98 (17 February 2004), paras 48ff.

${ }^{71} \mathrm{ECtHR}$, Azemi (n 63) paras 38ff.

${ }^{72} \mathrm{ECtHR}$, Öcalan (n 61) paras 83ff.

${ }^{73}$ ECtHR, Naït-Liman v Switzerland App no 51357/07 (5 March 2018), paras 173ff.

${ }^{74}$ ECtHR, Loizidou (n 63) paras 49-57; ECtHR, Ilaşcu (n 63) paras $310 \mathrm{ff}$ and 333ff; ECtHR, Chiragov (n 63) paras 167ff; ECtHR, Mozer (n 63) paras 96ff.

75 ECtHR, Al-Skeini (n 63) paras 133ff; ECtHR, Jaloud (n 63) paras 139ff; ECtHR, Hassan v the United Kingdom App no 29750/09 (16 September 2014), paras 74ff.

76 See Samantha Besson, 'The Extraterritoriality of the European Convention on Human Rights. Why Human Rights Depend on Jurisdiction and What Jurisdiction Amounts to' (2012) 25(4) Leiden Journal of International Law 857. 
to States' duties to ensure equivalence in the human rights protection offered under IO law, ${ }^{77}$ but also, in the context of the assessment of their concurrent responsibility, of the potentially joint attribution of IO conduct to States in case of effective control. ${ }^{78}$

Secondly, the ECtHR's jurisprudence of statehood has also contributed to the delineation between States and private actors. Indeed, the Court has long innovated in the field of States' positive duties to protect against private actors. $^{79}$ It has thereby prevented States from hiding behind the public/ private distinction to escape their human rights duties to protect. It has also furthered that distinction, however, by developing case-law on the attribution of conduct of certain private actors to States for purposes of ECHR responsibility $^{80}$ and on the immunities of States for their agents. ${ }^{81}$ With respect to attribution, however, one should emphasise that the ECtHR has mostly used States' positive duties to protect against private actors in order to condemn States in those case, without concern for the details of the grounds of attribution of those private actors' actions or omissions to the State. ${ }^{82}$ In a distinct line of jurisprudence, the ECtHR has also clearly favoured the protection of civil society against, but also by the State: it has done so through the protection of the human rights of political parties, ${ }^{83}$ but also of NGOs, ${ }^{84}$ and, as of late and in a much criticised line of cases, of corporations. $^{85}$

Although the ECtHR refers and, sometimes, even defers to the ICJ on matters of general rules of international law of statehood, it has also developed its own interpretations on many them. As a result, the ECtHR's international jurisprudence of 'democratic' statehood may not always be compatible with the ICJ's. This may be explained by its post-Second World War and especially post-Cold War emphasis on the internal organisation of statehood, and especially on the rights of the population underpinning State sovereignty.

${ }^{77}$ ECtHR, Waite and Kennedy v Germany App no 26083/94 (18 February 1999), paras 66ff; ECtHR, Bosphorus Hava Yolları Turizm ve Ticaret Anonim Şirketi v Ireland App no 45036/98 (30 June 2005), paras 149ff; ECtHR, Al-Dulimi and Montana Management Inc. v Switzerland App no 5809/08 (21 June 2016, Grand Chamber), paras 102ff; ECtHR, Al-Dulimi and Montana Management Inc. v Switzerland App no 5809/ 08 (26 November 2013, Chamber).

${ }^{78}$ ECtHR, Al-Jedda v The United Kingdom App no 27021/08 (7 July 2011), paras 74ff.

${ }^{79}$ ECtHR, Osman $v$ the United Kingdom App no 23452/94 (28 October 1998), paras 113ff; ECtHR, O'Keeffe v Ireland App no 35810/09 (28 January 2014), paras 143ff; ECtHR, Kelly and Others $v$ the United Kingdom App no 30054/96 (4 May 2001), paras 91ff.

${ }^{80} \mathrm{ECtHR}$, Ilaşcu (n 63) paras 310ff; ECtHR, Jaloud (n 63) paras 137ff.

${ }^{81}$ ECtHR, Fogarty $v$ the United Kingdom App no 37112/97 (21 November 2001), paras 22ff; ECtHR, Al-Adsani $v$ the United Kingdom App no 35763/97 (21 November 2001), 35ff; ECtHR, Jones and Others $v$ the United Kingdom, App nos 34356/06 and 40528/06 (14 January 2014), paras 199ff.

82 ECtHR, Costello-Roberts $v$ the United Kingdom App no 13134/87 (25 March 1993), paras $25 \mathrm{ff}$.

83 ECtHR, Refah Partisi (n 58); ECtHR, Yumak and Sadak v Turkey App no 10226/03 (8 July 2008).

${ }^{84}$ ECtHR, Centre for Legal Resources on behalf of Valentin Câmpeanu v Romania App no 47848/08 (17 July 2014).

85 ECtHR, Autronic AG v Switzerland App no 12726/87 (22 May 1990); ECtHR, OAO Neftyanaya Kompaniya Yukos v Russia App no 14902/04 (20 September 2011); ECtHR, Slovenia v Croatia (n 68). 
Two examples help illustrating this. The first one pertains to the (albeit very) indirect endorsement of the collective right to self-determination, ${ }^{86}$ and the second one to the indirect and de facto acknowledgement of a right to nationality under certain circumstances. ${ }^{87}$

\subsubsection{The CJEU and the managerial State}

The international law of statehood does not belong to the core of the CJEU's mandate to the extent that EU law does not directly regulate statehood. All the same, and to the extent that general international law applies to the EU and to EU Member States ${ }^{88}$ the Court has developed a jurisprudence of statehood ever since the late 1950s. Its jurisprudence of statehood therefore spans over more than sixty years.

What characterises the CJEU's jurisprudence of statehood has been the construction of what one may refer to as the 'managerial' (Member) ${ }^{89}$ State. It is a well-established critique of the CJEU indeed that it has contributed to (over)constitutionalising the market in EU law. It has done so by developing the principle of the primacy of EU law, including of EU internal market law, over domestic constitutional law and by therefore placing economic requirements at the same constitutional level as respect for the rule of law, democracy or fundamental rights under EU law. ${ }^{90}$

More specifically, the CJEU has gradually interpreted EU law as requiring the EU and its EU Member States to adopt a certain external and internal organisation, an organisation that favours the internal market over (certain selected) public interests. To that extent, the internal political organisation of the EU, and especially its division of powers between the EU and its Member States, as they result from the CJEU's jurisprudence, may be said to correspond perfectly to the neo-liberal blueprint. One of the institutional features of neo-liberalism is indeed what one refers to as a 'market-preserving federalism' or decentralisation. ${ }^{91}$ On that approach, (regional) economic governance should be separated from (domestic) politics, and the State should be turned into a manager of the economic policy adopted at the (regional) international level. As a matter of fact, the CJEU has also favoured another kind of market-preserving decentralisation, albeit within Member States this time, that is instrumental to the internal market. It has encouraged, provided

${ }^{86} \mathrm{ECtHR}$, Azemi (n 63) paras 38ff.

${ }^{87}$ ECtHR, Hoti (n 67) paras $119 \mathrm{ff}$.

${ }^{88}$ CJEU, C-162/96 Racke (16 June 1998), paras 45ff; T, Case T-115/94 Opel Austria v Council (22 January 1997), paras 89ff; CJEU, C-386/08 Brita (25 February 2010), paras $37 \mathrm{ff}$.

${ }^{89}$ See Christopher Bickerton, 'From Nation State to Member State. Trajectories of State Reconfiguration and Recomposition in Europe' in P Le Gales et D King (eds), Reconfiguring European States in Crisis (Oxford University Press, 2017) 45-71.

90 See Dieter Grimm, 'The Democratic Costs of Constitutionalization: The European Case' (2015) 21(4) European Law Journal 460.

91 See Adam Harmes, 'New Constitutionalism and Multilevel Governance' in S Gill and AC Cutler (eds), New Constitutionalism and World Order (Cambridge University Press, 2014) 143-58. 
they are in the interest of the internal market, forms of federalism, devolution or decentralisation within States' internal political organisation, ${ }^{92}$ on the one hand, and of privatisation of public services and 'functions' in that context, on the other. This has turned EU Member States into another kind of managers or 'orchestrators': ${ }^{93}$ not so much managers for the EU this time, but for the market activities of local public actors and private actors within their jurisdiction.

Of course, the CJEU's jurisprudence on managerial statehood has developed together with, and actually mirrors its jurisprudence pertaining to the EU itself. What characterises the EU indeed is the 'integration' of its Member States and their legal orders into a regional institution and legal order. When pressed to explain what integration amounts to, the Court has repeated that the EU is a sui generis entity that arose out of international law, but now amounts to a legal order of a new kind, neither domestic nor international. ${ }^{94}$ Recently, the Court confirmed that the EU is not a State. ${ }^{95}$ This has serious implications for all internal aspects of statehood that are shared by the EU and its Member States, and in particular for EU and domestic citizenship, democracy or rule of law. They have indeed been detached from what makes the legitimacy of the State and its laws, ie, its people, and have become free-floating conditions of political legitimacy tout court. Of course, some characteristics of statehood have not (yet) come within the (legal) reach of the $\mathrm{EU}$, and that is the case of sovereignty or jurisdiction. However, they have been pooled between EU Member States and simply go by other names when the EU exercises them such as 'competences' or 'powers'. The same applies to the criteria of statehood in international law, like territory, nationality, effective government or independence that are replaced, when the EU is at stake, by terms like 'space', 'citizenship', 'governance' or 'autonomy'. Increasingly, then, those new terms are shared interchangeably by both the EU and its Member States, thereby affecting the legal identity of EU Member States.

In the wake of its jurisprudence on the external and internal organisation of EU Member States as managerial States, the CJEU has also contributed to developing the international jurisprudence of statehood in general. With respect to statehood itself, on the one hand, the CJEU's jurisprudence on the interpretation and implementation of EU law pertains to all dimensions identified earlier in this section. First of all, the CJEU has revisited the constitutive criteria of statehood. It has been the case for territory, in particular, as

92 CJEU, C-428/07 Horvath (16 July 2009).

93 See Patrick Le Gales and Desmond King, 'Introduction. A Reconfigured State? European Policy States in a Globalizing World' in P Le Gales and D King (eds), Reconfiguring European States in Crisis (Oxford University Press, 2017) 1-42.

${ }^{94}$ CJEU, C-26/62 Van Gend \& Loos (12 December 1962), p 12; CJEU, Opinion 1/91 (14 December 1991), paras 21ff; CJEU, Opinion 2/13 (18 December 2014), paras 153ff.

95 CJEU, Opinion 2/13 (n 94), paras $153 \mathrm{ff}$. 
the CJEU has ventured into issues of border delimitations at sea, ${ }^{96}$ of border control on the ground ${ }^{97}$ and of overseas territories. ${ }^{98}$ The CJEU has also interpreted the notion of State nationality extensively in the context of its interpretation of EU citizenship because the latter derives from State nationality. ${ }^{99}$ It has in particular drawn a distinction in quality between the equal citizenship rights of other EU Member State nationals and the rights of third country nationals in a given EU Member State. ${ }^{100}$ The CJEU has further qualified the international law regime of State nationality itself by adding conditions to fulfil in case of loss of EU Member State nationality (and hence of EU citizenship) based on domestic law. ${ }^{101}$ It has also specified some of the rights derived from State nationality, with respect to an EU citizen's name for instance ${ }^{102}$ or to the minimal right not to leave the EU. ${ }^{103}$ Another feature of the CJEU's jurisprudence pertaining to EU citizenship qua economic citizenship has been to require EU Member States to differentiate between economically and non-economically active nationals of other EU Member States to the extent that EU citizenship rights are reserved to the former. ${ }^{104}$ States have also been requested to distinguish between third country nationals and EU Member State nationals on grounds of nationality without that ground being considered discriminatory under EU law. ${ }^{105}$

Secondly, the CJEU has also contributed to the interpretation of the beginning and the end of statehood, by specifying States' duties in the context of State succession ${ }^{106}$ and recognition. ${ }^{107}$ The Court has even emphasised the erga omnes nature of the right to self-determination and the related State duty of non-recognition that a violation of that right generates for other States including EU Member States and the EU itself, although it did not have to resort to those arguments to settle the cases in the end. ${ }^{108}$ Thirdly,

${ }^{96}$ CJEU, C-146/89 Commission v United Kingdom and Northern Ireland (9 July 1991).

${ }^{97}$ CJEU, C-606/10 ANAFE (14 June 2012), paras 23-9; CJEU, C-278/12 PPU Atiqullah Adil (19 July 2012), paras $48-58$.

${ }^{98}$ CJEU, C-591/15 The Gibraltar Betting and Gaming Association (13 June 2017), paras 26ff; CJEU, C-300/04 Eman and Sevinger (12 September 2006), paras $20 \mathrm{ff}$.

99 CJEU, C-369/90 Micheletti (7 July 1992), paras 11 ff; CJEU, C-192/99 Kaur (20 February 2001), paras 19-27.

${ }^{100}$ CJEU, C-145/04 Spain v United Kingdom (12 September 2006), paras 72-80.

101 CJEU, C-135/08 Rottmann (2 March 2010).

102 CJEU, C-168/91 Konstantinidis (30 March 1993); CJEU, C-353/06 Grunkin and Paul (14 October 2008).

103 CJEU, C-34/09 Ruiz Zambrano (8 March 2011); CJEU, C-165/14 Rendón Marín (13 September 2016); CJEU, C- 133/15 Chavez-Vilchez e.a. (10 May 2017).

104 CJEU, C-184/99 Grzelczyk (20 September 2001), paras 29ff; CJEU, C-224/98 D'Hoop (11 July 2002), paras 27ff; CJEU, C-85/96 Martínez Sala (12 May 1998), paras 29ff; CJEU, C-209/03 Bidar (15 March 2005), paras 28ff; CJEU, C-158/07 Förster (18 November), paras 25ff; CJEU, C-73/08 Bressol and Others (13 April 2010), paras 40ff.

105 CJEU, C-22/08 Vatsouras (4 June 2009); CJEU, C-291/09 Francesco Guarnieri \& Cie (7 April 2011); T, T$618 / 15$ Voigt v Parliament (20 November 2017).

${ }^{106}$ CJEU, C-216/01 Budvar (18 November 2003).

107 CJEU, C-50/90 Sunzest v Commission (13 June 1991); CJEU, C-432/92 Anastasiou (5 July 1994).

108 CJEU, C-104/16 P Front Polisario (21 December 2016), paras 86-108; CJEU, C-266/16 Western Sahara Campaign UK (27 February 2018, grand Chamber), paras 61-9. 
the CJEU has interpreted the content of some of the powers and rights of statehood, and in particular the scope of territorial jurisdiction ${ }^{109}$ or protective jurisdiction including its extraterritorial consequences. ${ }^{110}$ The CJEU has further ventured into interpreting State immunities. ${ }^{111}$

Finally, the CJEU has also been concerned with EU Member States' internal organisation. It has been the case with respect to their political regime in particular. In that context, the Court has interpreted EU law as requiring from States that they endorse principles such as the separation of powers, the rule of law, parliamentary democracy, ${ }^{112}$ fundamental rights, ${ }^{113}$ judicial independence, ${ }^{114}$ judicial review, ${ }^{115}$ or transparency/access to documents. ${ }^{116}$

On the other hand, the CJEU's jurisprudence of statehood has also contributed to developing issues in the second axis of the international law of statehood. First of all, the Court has developed an extensive case-law on the EU's internal relations to its Member States, but also on its external relations to other States and other IOs. A telling example of the CJEU's jurisprudence in this respect is its interpretation of the international responsibility of the EU in case of breach of international law by an EU Member State acting within the scope of EU exclusive or shared competences. ${ }^{117}$ In this context, EU Member States are not approached as 'organs' of the EU in the sense in which a State organ may be placed at the disposal of an IO (article 7 Draft Articles on the Responsibility of International Organizations $2011^{118}$ ), but they are regarded as domestic managers of EU law matters and responsibility should therefore be borne exclusively by the EU. The CJEU has also famously considered that EU constitutional law could take priority over EU law implementing UN Security Council resolutions, with the same consequences for EU Member States, including permanent members of the Security Council. ${ }^{119}$ All the same, there have also been cases in which the CJEU has been reluctant to

${ }^{109}$ CJEU, C-420/07 Apostolides (28 April 2009), paras 47-71.

110 CJEU, C-424/13 Zuchtvieh-Export (23 April 2015), paras 34ff; CJEU, C-592/14 European Federation for Cosmetic Ingredients (21 September 2016), paras 28ff; CJEU, C-230/14 Weltimmo (1 October 2015), paras 19ff; CJEU, C-591/15 Gibraltar Betting (n 98) paras $26 \mathrm{ff}$.

111 CJEU, C-179/13 Evans (15 January 2015); CJEU, C-154/11 Mahamdia (19 July 2012).

112 CJEU, C-441/05 Roquette Frères (8 March 2007); CJEU, C-190/84 Les Verts v Parliament (25 February 1988); T, T-365/04 Cantoni v Council and Commission (18 December 2009); T, T-754/14 Efler v Commission (10 May 2017); CJEU, C-589/15 P Anagnostakis v Commission (12 September 2017), paras 23-4.

113 CJEU, C-29/69 Stauder (12 November 1969); CJEU, C-4/73 Nold v Commission (14 May 1974; CJEU, C-36/ 75 Rutili (28 October 1975).

${ }^{114}$ CJEU, C-64/16 Associação Sindical dos Juízes Portugueses (27 February 2018); CJEU, C-216/18 PPU LM (25 July 2018).

115 CJEU, C-432/05 Unibet (13 March 2007); CJEU, C-188/10 and C-189/10 Aziz Melki and Sélim Abdeli (22 June 2010).

${ }^{116}$ CJEU, C-280/11 P Council v Access Info Europe (17 October 2013).

117 CJEU, C-213/03 Pêcheurs de l'Etang de Berre (15 July 2014).

118 ILC, 'Draft Articles on the Responsibility of International Organizations' (2011) II(2) Yearbook of the International Law Commission 40.

${ }^{119}$ CJEU, C-402/05 P Kadi v Council and Commission (3 September 2008). 
meddle with EU Member States' international relations and their international law regime. It has been the case with respect to the international law of diplomatic relations in particular. ${ }^{120}$

Secondly, the CJEU's jurisprudence of statehood has also contributed to the delineation between States and private actors. This has been of prime importance for the effectivity of the EU's internal market law. Thus, the CJEU has identified criteria to distinguish State institutions from private undertakings in the areas of State aids, golden shares and competition law. So-doing, the Court aimed at unmasking both cases where the State is pretending to be a private actor and cases where the State is camouflaging private actors as public ones. ${ }^{121}$ Interestingly, instead of defining the private sector, and its actors, negatively by reference to the State, as has been done in State political theory and public law since the eighteenth Century, the CJEU has reversed the direction of the distinction: it relies on the market and free competition in those cases as a negative functional criterion for the identification of public actors. ${ }^{122}$

Although the CJEU refers, and sometimes even defers to the ICJ on matters of general rules of international law of statehood, it has also developed its own interpretations on many of them. This may be explained by its emphasis on the external and internal organisation of what one may call 'market statehood', and especially on the priority of the market and the protection of private actors. Two examples confirm this: one from the field of EU citizenship jurisprudence, and its discriminatory implications for the acquisition and loss of EU Member State nationality, ${ }^{123}$ and the other from the field of EU trade policy, and the loosening of the conditions of State recognition. ${ }^{124}$

\section{Criticising and reforming the international jurisprudence of statehood}

\subsection{Three critiques of the international jurisprudence of statehood}

Three critiques of the international jurisprudence of statehood just presented need addressing in particular: its imperialism; its techno-scientificity; and its de-politicisation.

\footnotetext{
${ }^{120}$ CJEU, C-364/10 Hungary v Slovakia (16 October 2012); CJEU, C-466/11 Currà e.a. (12 July 2012).

121 CJEU, C-355/01 AOK-Bundesverband and Others (16 March 2014), paras 45ff; CJEU, C-41/90 Höfner and Elser (23 April 1991); CJEU, C-222/04 Cassa di Risparmio di Firenze C-222/04 (10 January 2006), paras107ff; CJEU, C-35/99 Arduino (19 February 2002), paras 32-44. See Miguel Poiares Maduro, 'The Chameleon State: EU Law and the Blurring of the Private/Public Distinction in the Market' in N Rainer (ed), Conflict of Laws and Laws of Conflict in Europe and Beyond: Patterns of Supranational and Transnational Juridification (Intersentia, 2010) 279-92.

122 CJEU, C-136/86 Aubert (3 December 1987); CJEU, Commission v Italy C-251/17 (31 May 2018); CJEU, Arduino (n 121) paras 32-44.

123 CJEU, Vatsouras (n 105) paras 33-53; CJEU, Guarnieri (n 105) paras 11-21; T, Voigt (n 105) paras 74-81.

${ }^{124}$ CJEU, Sunzest (n 107); CJEU, Anastasiou (n 107).
} 
The first critique pertains to the imperialism of the international jurisprudence of statehood. ${ }^{125}$ It emphasises how ICs, and the PCIJ and ICJ in particular, have identified European and then Western criteria of statehood and various principles pertaining not only to the beginning and the end of statehood, but also to States' rights and duties and, later on, to their internal organisation, and turned them into international law. Whether this has been done by mere judicial law-making independently from customary law in the area, on the one hand, or by the transformation of what was already a regional custom in Europe and the West into a universal one, on the other, the critique bites equally.

Of course, as I explained before, statehood has now been successfully universalised by international law and the jurisprudence of ICs, at least formally. The consequences of its imperialistic internationalisation are still being felt in most places, however. In many regions outside the West, indeed, States have remained empty shells, ghost presences hiding a political void or inhabited by other political or communal forms, religious or not, that have not accommodated to the parallel State structure, thereby leading to tensions and instability. ${ }^{126}$ It is surprising therefore that contemporary interpretations by ICs do not refer more than original ones to the current domestic practices of statehood outside of the West, in particular in order to make the new international jurisprudence of statehood more inclusive. This would seem to be even more required as the internationalisation of statehood through ICs carries on, but this time with respect to new aspects of the international law of statehood. It has been the case for those originally Western norms pertaining to the internal organisation of States, and in particular those related to their democratic regime and political organisation (eg, political parties), but also to the private/public divide (eg, civil society, NGOs) and States' relations to private actors.

This critique does not only apply to the ICJ's jurisprudence of statehood, but also to the ECtHR's where variations in the political and legal conceptions of statehood within Europe have never been seriously considered and alternative conceptions are usually disparaged as plainly abusive. If we want to overcome human rights formalism in Turkey or Russia and reach behind the façade of pseudo-democratic statehood and the false pretence of those and other Council of Europe States regarding the effective protection of human rights in practice, we need to take alternative domestic forms of political organisation or, at least, different domestic contextualisations of various

125 See eg, Rosalyn Higgins, 'The International Court of Justice and Africa' in R Higgins (ed), Themes and Theories: Selected Essays, Speeches, and Writings in International Law (Oxford University Press, 2009) 1056-71; Sundhya Pahuja, 'Laws of Encounter: A Jurisdictional Account of International Law' (2013) 1 London Review of International Law 63; Luis Eslava and Sundhya Pahuja, 'The Nation-State and International Law: A Reading from the Global South' (2019) 10 Humanity: An International Journal of Human Rights, Humanitarianism and Development (forthcoming).

${ }^{126}$ See also Badie (n 12). 
aspects of statehood more seriously. The same should be said about the CJEU and the way it has dealt so far with certain aspects of the internal organisation of statehood in Hungary or Poland by simply transposing Western or Northern conceptions of the State onto States in the East or South of Europe. ${ }^{127}$

The second, and related, critique of the international jurisprudence of statehood pertains to its techno-scientificity. ${ }^{128}$ What is at stake here is the tendency of the international jurisprudence of statehood to contribute to the diffusion of a set of objective techno-scientific standards of statehood, usually of an economic kind, that are beyond justification or normative critique. Unlike legal principles or rules, those standards are not there to hold State authority accountable to people subjected to State laws and justify it, but merely to assert and then verify its authority over them. This is what some authors like Bhuta have referred to as 'State-science'. ${ }^{129}$

Thus, one may cite the standards, and their indicator-based measures, of 'developmental statehood', and more recently of 'entrepreneurial statehood'. ${ }^{130}$ The most recent case of the former model of statehood is, of course, the one encapsulated in the 2015 Sustainable Development Goals and their many targets and indicators (UN General Assembly Resolution 70/1). A jurisprudential example to point to with respect to the latter is the CJEU's implicit reversing of the direction of one of the oldest and most fundamental distinctions in the Western legal tradition, ie, the distinction between the public and the private. The Court draws indeed on the market in order to identify what should be the 'functions' of public authorities rather than the other way around. ${ }^{131}$ The CJEU has also contributed to imposing a Northern conception of the 'entrepreneurial State' as part of the austerity regimes on Southern EU Member States. ${ }^{132}$

A third, and related, critique of the international jurisprudence of statehood focuses on its de-politicisation. ${ }^{133}$ It pertains to the growing disconnection therein between the State and the population whose political community the State personifies as a legal fiction and, by extension, to the comparability and even assimilation between States' governmentality and any form of 'governance' including economic governance.

${ }^{127}$ CJEU, Sindical dos Juízes Portugueses (n 114) paras 27-52; CJEU, LM (n 114).

${ }^{128}$ See eg, Koskenniemi, 'The Fate of Public International Law' (n 5).

129 See Nehal Bhuta, 'State Theory, State Order, State System - Jus Gentium and the Constitution of Public Power' in S Kadelbach, T Kleinlein and D Roth-Isigkeit (eds), System, Order and International Law: The Early History of International Legal Thought from Machiavelli to Hegel (Oxford University Press, 2017) 398-417.

130 See Eslava/Pahuja (n 125).

131 CJEU, Aubert (n 122); CJEU, Commission v Italy (n 122); CJEU, Arduino (n 121).

132 CJEU, C-128/12 Sindicato dos Bancários do Norte and Others (7 March 2013).

133 See Martti Koskenniemi, 'The Future of Statehood' (1991) 32 Harvard International Law Journal 397; Martti Koskenniemi, 'The Wonderful Artificiality of States' (1994) 88 Proceedings of the ASIL Annual Meeting 22. 
Of course, it is easy to understand when, in the history of statehood, that connection was lost, both in practice and theory. Shortly after the nineteenth Century's liberal anthropomorphism and the assimilation of States to real or natural persons, utilitarian political thinkers rejected all legal fictions including that of the State and its personification as a legal person. They reduced each State to its government and State law's authority to coercion, thereby evacuating the political dimension of statehood and losing sight of the representation relationship between the State (personifying the political community) and its government. ${ }^{134}$ The international law of statehood of the early twentieth Century clearly reflected this utilitarian conception of statehood. That trend was even reinforced with the development of IOs whose driving justification was and, to a large extent, still is functionalist. That instrumental conception of authority was then re-imposed onto (Member) States through IO law. This is well exemplified by the CJEU's turning EU Member States into managerial States.

True, in the meantime, the connection between the State and its population has clearly been re-emphasised in other parts of international law that emerged after the second World War and were reinforced at the end of the Cold War, and in international human rights law in particular. The internal dimension of the international law of statehood, and especially its part pertaining to States' democratic regime are there to remind us thereof. One may understand therefore that the early international jurisprudence of statehood, and especially the ICJ's, placed priority on other criteria of statehood than the population and personal jurisdiction, giving priority most of the time to territory (or effective government over a territory) when deciding whether a 'non-self-governing entity' was a State. ${ }^{135}$ The fact that that conception has been resilient throughout the twentieth Century and to this date, however, is problematic. It suffices in this respect to consider the ICJ's recent opinions and their neglect of the popular and political dimension of the right to self-determination. ${ }^{136}$ Of course, there are signs of dissidence on the part of some ICs, and especially of the ECtHR, ${ }^{137}$ but they have been very slow and cautious so far.

\subsection{Three reform proposals for the international jurisprudence of statehood}

Some authors criticise the current state of the international law of statehood without making any proposals for reform ${ }^{138}$ or, worse, consider that any

\footnotetext{
${ }^{134}$ See Quentin Skinner, 'The Sovereign State: A Genealogy', in Q Skinner and H Kalmo (eds), Sovereignty in Fragments: The Past, Present, and Future of a Contested Concept (Cambridge University Press, 2010), 4044.

${ }^{135} \mathrm{ICJ}$, Western Sahara (n 13) paras $79 \mathrm{ff}$.

${ }^{136}$ ICJ, Kosovo (n 35) paras 79ff; ICJ, Wall (n 46) paras 87ff. See, however, ICJ, Chagos Archipelago (n 46) para 160.

137 ECtHR, Azemi (n 63) paras 38-49.

${ }^{138}$ See Pahuja (n 125); Eslava/Pahuja (n 125).
} 
attempts at fixing things within international law are doomed to fail. ${ }^{139}$ Authors who hold those positions underestimate the resources of law and of international law in particular. They are wrong, in particular, to assume that international law can only be imperialistic, anthropomorphic and legalistic, and that international adjudication can only be of the liberal kind we know of in Western States. It may have been the case in the past, but those characteristics are no more a curse in international law than they have been in the domestic legal order. As a matter of fact, as I will argue, ICs are best placed within the current institutional structure of international law-making, and due to their unique qualities of judicial reasoning, to develop the kind of jurisprudence of statehood we need to address international institutional challenges.

The promise of self-determination that came with equal statehood under international law has been broken, not to mention the promise of economic development that came later in its wake. The result has been, as we all know, global instability and disorder. It is urgent therefore to make the most of international law and its promise of universality and individual equality while it still binds. This implies making sure that the equality of States that vouches, however imperfectly, for our individual equality across borders also amounts to equality in the making of the future international law of statehood. However parochial its origins and imperfect its implementation, statehood is indeed what the different peoples inhabiting the world now have in common and what enables them to be 'forming a world together' ${ }^{140}$ thanks to international law.

\subsubsection{Comparing the international law of statehood}

A first way to reform the international jurisprudence of statehood so as to make it more universal in content, and thereby address the critique of imperialism, would be to include, compare and distinguish conceptions of the State, from different parts either of the world at the ICJ or of the European region at the ECtHR or CJEU.

Of course, as most State theorists know, there could be as many conceptions of statehood as there are States. Commonalities can surely be sought for and found, however, without perpetuating the imposition of the Western liberal conception of statehood on other States in the world or of Western or Northern conceptions on Eastern and Southern States in Europe. There is a path, albeit a narrow one, between imperialism and sheer relativism, and hence between unicity and radical difference.

One way to make the international jurisprudence of statehood more universal is to resort to an important albeit currently neglected resource in

\footnotetext{
${ }^{139}$ See d'Aspremont, 'The International Law of Statehood' (n 9); d'Aspremont, 'Statehood and Recognition' (n 9).

140 Hannah Arendt, On Revolution (Penguin, 1963) 175.
} 
international law-making: comparative international law. Its point is to compare how a given rule, principle or institution of international law is interpreted and practiced in domestic law (this is what one may refer to as 'comparative international domestic law'), but also how it is interpreted in different regimes and by different ICs ('comparative international law' sricto sensu). The latter corresponds to what has been done, albeit on a more modest scale, in this article and should contribute to bringing not only more nuance and dialogue, but also more coherence in the fragmented international jurisprudence of statehood. The former may imply resorting to the comparison of domestic jurisprudences of statehood. Developing such a comparative jurisprudence of statehood is even more important as domestic courts are often the ones enforcing and hence interpreting and developing the international law of statehood. It is the case, for instance, in areas of the international law of statehood such as immunities, recognition or succession. ${ }^{141}$ Given the diversity of theories and practices of statehood across States, the best place to start is probably through regional comparisons of the domestic jurisprudence of statehood. ${ }^{142}$

By comparison to other international institutions and especially other IOs' organs, ICs are actually well placed in terms of the kind and quality of their reasoning to launch such comparative discussions of statehood in their jurisprudence. ICs are, first of all, routinely confronted with issues of statehood stemming from all States around the world. Practically, therefore, they are in possession of legal material that may enable them to conduct a comparative law study in each case. It is, of course, especially the case of the ICJ, but regional courts like the ECtHR and the CJEU present the same features at the regional level. Secondly, ICs are usually composed of judges that should be representative of legal and political cultures, either of the world for the ICJ or within the region for regional ICs. This can contribute to enhance their epistemic ability to conduct the required comparative studies, with others or 'single-judgedly'. ${ }^{143}$ Finally, the authority of ICs' jurisprudence of statehood is broad, whether on the universal plane for the ICJ or on a regional one for the ECtHR or the CJEU, and this is essential in an area of general international law that affects all States like the international law of statehood. This feature explained why the ICJ remained attractive to States as an international law-maker even when the Western bias of its conception of statehood

${ }^{141}$ See Alexander Orakhelashvili, 'The Dynamics of Statehood in the Practice of International and English Courts' in C Chinkin and F Baetens (eds), Sovereignty, Statehood and State Responsibility: Essays in Honour of James Crawford (Cambridge University Press, 2015) 172-91.

142 See Samantha Besson, 'The Influence of the Two Covenants on States Parties across Regions - Lessons for the Role of Comparative Law and Regions in International Human Rights Law' in D Moeckli, H Keller and C Heri (eds), The Human Rights Covenants at 50. Their Past, Present and Future (Oxford University Press, 2018) 243-76.

143 See eg, Judges Ammoun, Forster, and Boni, Separate Opinions, ICJ, Western Sahara (n 13) 83ff, 103, and $173 f$. 
was clear to non-Western States. ${ }^{144}$ The broader the claimed authority of an IC, however, the more important it is to its justification, and hence to its legitimacy, that its reasoning be comparative and that it take all States Parties' conceptions seriously. ${ }^{145}$

Interestingly, some ICs already practice comparative domestic and international law in their standard judicial reasoning. It would not therefore take too much work to extend comparative reasoning to their respective jurisprudence of statehood. It is the case of the ECtHR's whose subsidiary review has led it to first identify a European consensus among States Parties on the issue at stake and then to modulate its own degree of review by reference to that consensus. The same may be said of the CJEU even if recent years have seen less comparative law in the reasoning of the Court, including in the areas where it is most needed like EU fundamental rights or other issues related to EU Member States' constitutional identity.

\subsubsection{Justifying the international law of statehood}

A way to reform the international jurisprudence of statehood so as to make it less technical in content, and thereby address the critique of its lack of normativity, would be to enhance the quality of ICs' reasoning.

Improving the normative quality of international judicial reasoning pertaining to statehood should in principle be within reach. International judges, like domestic judges, have the capacity to be true moral reasoners and, arguably, also have the responsibility to reason in such a way as well. Unlike international law-making in other organs of an IO or in treaty conferences, international judicial law-making knows only of constraints related to reasoning. To the extent that those constraints are respected, therefore, one may hope for contestation of the functionalist and instrumental regulation of statehood adopted by other organs of the IO. Moreover, international judges are or, at least, should be selected among the best international lawyers in their respective countries or regions. Their domestic training should enable them not only to contribute effectively to the comparative statehood exercise discussed before, but also vest them with the relevant domestic legal knowledge and experience to enhance the quality of international judicial reasoning on statehood. Finally, the plurality of ICs, and their tendency to refer to one another and especially to the ICJ in their jurisprudence of statehood, may even be a virtue in this context as it can help launch an open comparative and theoretical dialogue between courts.

More specifically, the international jurisprudence of statehood could be reformed so as to reveal more openly what underpinning political and legal

\footnotetext{
${ }^{144}$ See Ibrahim Shihata, 'The Attitude of New States Towards the International Court of Justice' (1965) 19 International Organizations 203.

145 See Besson (n 142).
} 
theories of statehood are being discussed and used in the justification of the interpretations of the international law of statehood selected in each case. When one knows how many controversies in political and legal theory there have been around statehood, it is difficult to imagine judges could avoid entering into some of them in their judgments and having to develop the clear conception of the structure and justification of the international legal order that necessarily goes with them. A comparative discussion of domestic jurisprudences actually also implies a readiness to compare and distinguish the variety of (eg, Hobbesian, Jellinekian or Weberian ${ }^{146}$ ) theories of the State underpinning those legal regimes.

\subsubsection{Politicising the international law of statehood}

A third proposal to reform the international jurisprudence of statehood so as to make it more political in content, and thereby address the critique of their lack of reference to representation, would be to re-situate the people or political community the State personifies at the core of the international law of statehood.

Fitting in the political community and its personification by the State into the jurisprudence of statehood requires, for instance, that ICs openly confront issues of self-determination, but also of State succession. It also means linking territoriality to the population and personal jurisdiction over that population situated in a given territory when assessing statehood rather than conceiving of territorial jurisdiction independently of that population and its politics. ICs should also conceive of States' relations to other institutions, public or private, as political relations rather than as relations of governance. After all, the early ICJ's case-law did refer to the UN, and other IOs, as 'bodies politic' in the $1960 \mathrm{~s},{ }^{147}$ and one would need to read more today in its case-law about how those political institutions relate not only to States but to their population. Of course, the jurisdiction of some ICs may have to be amended in order to enable them to receive applications and questions pertaining to contemporary political and institutional questions in international law.

At this stage, one may object that ICs are precisely not the international institutions one should expect or want to be 'political' or, at least, to reason about States in a way that reveals their political dimension and legitimacy. ${ }^{148}$ It is arguably complicated enough to interpret international law on a universal or regional plane, and meddling with the political dimension of international law would only make things more controversial. That may be true, but there is no way around this problem. It will not disappear by being hidden away behind a legal formalist curtain and by giving into functionalist

\footnotetext{
${ }^{146}$ See eg, Andrew Vincent, Theories of the State (Basil Blackwell, 1987).

147 See ICJ, Certain Expenses (n 54) pp 167-8.

${ }^{148}$ See Keller/Heri (n 61) 122.
} 
considerations. We actually know this from domestic public law: constitutional law judges have to decide on such issues daily and do no shy away from the political dimension of the organisation of our public institutions when doing so.

Of the three ICs discussed, there is one that clearly already embraces its political role, despite the many controversies this has brought onto it, and that is the ECtHR. It needs to do so even more openly in the area of statehood, however, first by acknowledging its jurisprudence on the topic, standing for it and building it up even further. As I argued before, doing so comparatively and normatively may help assuaging States' resistance by opening to various domestic conceptions and theories of statehood, by respecting subsidiarity in international statehood review and hence by approaching the international law of statehood as the common enterprise it was meant to be.

\section{Conclusions}

Why should contemporary international lawyers still care about the law of statehood? And why should anyone expect contemporary ICs to have anything meaningful to say about States?

I hope to have made at least four points towards replying to the second question: first, various ICs have and are still contributing in a decisive fashion to the international law of statehood; second, they have done so in various ways, thereby leading to the development of a plurality of types of statehoods under international law, either internationalised, democratic or managerial and, sometimes, all of them at the same time; third, the jurisprudence of statehood of those various ICs can and should be criticised for what they have done and/or are doing to States and ultimately to their citizens, by allowing the international law of statehood to develop in a largely imperialistic, techno-scientific and de-politicised way; and, finally, the international jurisprudence of statehood can and should also be reformed to become more universal, more normative and more political.

To go back to the first question, the reason international lawyers should care about statehood is that without a good grasp of States we cannot hope to conceive and organise other international institutions, public or private. At a time when no one knows exactly who is represented by whom on the international plane, why those who make international law may actually claim to bind us and who should be accountable to us in case of breach of international law, this matters. With the international law of statehood, indeed, we have gathered at least some answers to those questions, answers it took centuries to debate over and carve out. This is why it is with them, and their current legal status rather than a mythological Westphalian concept, that we should try to find the answers to the new questions other international institutions raise for us. 
This is not only a nice theoretical endeavour, but a question of great practical urgency, both in the West and beyond. Indeed, if one refers to the norms of the international law of statehood, as they have been gradually developed by the jurisprudence of ICs over a century, most States on the planet would be considered as 'failed' or, to use a more recent and politically correct term, as 'limited' in their statehood. Why not consider, on the contrary, that it is international law itself and in particular the international law of statehood that failed those States? In the second half of the twentieth Century, the international law of statehood came with guarantees of new rights: equality for States and ultimately for their citizens, of course, but also self-determination, democracy and human rights. If we, international lawyers, are not true to those guarantees, we will have failed the international dimension of the modern project of statehood.

To quote Judge Forster in Western Sahara, the problem lay originally in the ICJ requiring, in its early case-law, that all States be 'carbon copies of European institutions. ${ }^{149}$ Nowadays, as I explained, the lack of interest of international lawyers for contextualisation and comparison in lieu of top-down uniformisation is still a problem, and so is the lack of concern for the moral justifications of statehood instead of techno-scientific truths or economic standards, and, more generally, for political government instead of economic governance. It is time for a change. One way to provoke this kind of reform and trigger international institutional innovation may actually be to make the most of the plurality of ICs and their existing jurisprudence of statehood rather than turn our back on them.

\section{Acknowledgments}

I would like to thank Andreas Føllesdal and Geir Ulfstein for the invitation, Helen Keller and Øyvind Østerud for comments, and members of the audience for questions. Many thanks to Adrien Folly for his research assistance and to Sofia Balzaretti for her editorial assistance.

\section{Disclosure statement}

No potential conflict of interest was reported by the author. 